\title{
Body position of the stink bug Dichelops melacanthus (Dallas) during feeding from stems of maize seedlings
}

\author{
A. R. Panizzi ${ }^{a *}$ and T. Lucini ${ }^{b}$ \\ a Laboratório de Entomologia, Embrapa Trigo, Empresa Brasileira de Pesquisa Agropecuária - EMBRAPA, \\ BR 285, Km 294, CP 3081, CEP 99001-970, Passo Fundo, RS, Brasil \\ bDepartamento de Zoologia, Universidade Federal do Paraná - UFPR, Av. Cel. Francisco H. dos Santos, 100, \\ Jardim das Americas, CP 19020, CEP 81531-980, Curitiba, PR, Brasil \\ *e-mail: antonio.panizzi@embrapa.br
}

Received: July 10, 2017 - Accepted: October 5, 2017 - Distributed: May 31, 2019

(With 4 figures)

\begin{abstract}
The Neotropical green-belly stink bug, Dichelops melacanthus (Dallas) is a major pest of maize, Zea mays L. in the main production areas of Brazil. It usually feeds on the stems of young plants (seedlings) causing heavy damage by affecting the plant growth and mitigating seed yield. Laboratory studies were conducted to determine body position (upward or downward) of the bug on plant (seedling) stem during feeding and not feeding activities. Ten visual records were taken per day, each spaced one hour during 30 days of 10 adult bugs of similar age exposed to maize seedlings inside cages (plastic tubes). At each observation, it was recorded if the bug was feeding on the stem (i.e., stylets inserted into the plant tissue) or not, and its body position. During feeding, waveforms were recorded using the EPG (electropenetrography) technique, which were correlated with histological studies to reveal the feeding sites. Results indicated that when they were feeding, the majority of the bugs were in the downward position. In contrast, when the bugs were on the plants, and not feeding, they were mostly in the upward position. Waveforms generated using the EPG coupled with histological studies demonstrated that during ingestion bugs fed from the xylem vessels and from the parenchyma tissue using cell rupture strategy in the latter. No clear explanation was found to explain the preferred downward body position during ingestion, but some hypothesis are speculated.
\end{abstract}

Keywords: Heteroptera, Pentatomidae, feeding behavior, EPG, plant histology.

\section{Posição do corpo do percevejo Dichelops melacanthus (Dallas) durante a alimentação em hastes de plântulas de milho}

\section{Resumo}

O percevejo barriga-verde, Dichelops melacanthus (Dallas) é uma praga importante do milho, Zea mays L. nas principais áreas produtoras do Brasil. Usualmente alimenta-se nas hastes de plantas jovens (plântulas) causando danos severos no seu crescimento e reduzindo o rendimento de grãos. Estudos foram conduzidos em laboratório para determinar a posição do corpo (voltado para cima ou para baixo) dos percevejos nas hastes das plântulas de milho durante as atividades de alimentação e não-alimentação. Foram feitas dez observações por dia, espaçadas por uma hora, durante 30 dias em 10 percevejos adultos com idade semelhante sobre plântulas de milho colocadas em gaiolas (tubos de plástico). Em cada observação, anotou-se se o percevejo estava se alimentando (i.e., estiletes bucais inseridos no tecido vegetal) ou não, e a posição do corpo. Durante a alimentação, ondas eletromagnéticas foram registradas utilizando-se o EPG (técnica da eletropenetrografia), as quais foram correlacionadas com estudos histológicos para revelar os locais de alimentação. Os resultados indicaram que quando os percevejos estavam se alimentando, a maioria estava voltado para baixo. Em contraste, os percevejos sem se alimentar nas plântulas estavam a maioria voltados para cima. As ondas geradas pelo EPG junto com os estudos histológicos revelaram que os percevejos se alimentaram dos vasos do xilema e do tecido parenquimatoso usando a estratégia de ruptura celular no último. Não foi encontrada uma explicação clara para a preferência dos percevejos em se alimentarem na posição voltados para baixo, mas algumas hipóteses são especuladas.

Palavras-chave: Heteroptera, Pentatomidae, comportamento alimentar, EPG, histologia da planta. 


\section{Introduction}

Phytophagous stink bugs (Heteroptera: Pentatomidae) are known to have preference to feed on reproductive structures (fruits and seeds) of their host plants (Schuh and Slater, 1995). However, some species feed on vegetative structures more often than on fruits and seeds. For example, the Neotropical brown-winged stink bug, Edessa meditabunda (F.), and the stem rice stink bug, Tibraca limbativentris Stål are commonly reported to feed on stems of soybean, Glycine max (L.) Merrill (Galileo and Heinrichs, 1979; Silva et al., 2012), and rice, Oryza sativa L. (Rizzo, 1976), respectively.

Some stink bug species that prefer to feed on reproductive structures, may use vegetative (leaflets and stems) plant parts as food sources, when their preferred food is not available. For example, the polyphagous so called green-belly stink bugs (in Brazil), Dichelops melacanthus (Dallas) and Dichelops furcatus (F.) feed on vegetative structures of maize, Zea mays L. and wheat, Triticum sativum L. plants, when reproductive structures (soybean pods) are absent (Ávila and Panizzi, 1995; Chocorosqui and Panizzi, 2004; Manfredi-Coimbra et al., 2005; Panizzi et al., 2015).

A curious behavior has been observed for pentatomid species while on stems of host plants, positioning their body downward (head pointed down) rather than displaying their body upward (head pointed up). For example, E. meditabunda was reported to present this behavior on soybean stem (Panizzi and Machado-Neto, 1992), as well as T. limbativentris on rice (Ferreira and Martins, 1984) and D. melacanthus on stem of maize seedlings (Ávila and Panizzi, 1995).

No information is available in the literature to compare and quantify stink bugs body position (i.e., downward or upward) while on stems of host plants, and if they prefer to stay in a particular position while feeding or not. Therefore, we evaluated the body position of the pentatomid, D. melacanthus on stems of maize plants, during feeding and not feeding activities. In addition, during feeding we recorded waveforms generated using the EPG (electrical penetration graph or electropenetrography) technique and coupled them with histological studies to confirm the feeding sites. Finally, this information was discussed related to body position.

\section{Materials and Methods}

\subsection{Stink bug colonies and plants}

Adults (ca. 60 specimens) of D. melacanthus were collected in Francisco Beltrão, Paraná state, Brazil (26 $04^{\circ}$ ' S; $\left.53^{\circ} 03^{\prime} \mathrm{W}\right)$. Insects collected have been brought to the laboratory of entomology at the Embrapa Trigo in Passo Fundo, RS, Brazil (28 $\left.15^{\prime} \mathrm{S}, 52^{\circ} 24^{\prime} \mathrm{W}\right)$, and placed into separated rearing cages $(25 \times 20 \times 20 \mathrm{~cm})$, lined with filter paper, with a natural food source composed by fresh green bean pods (Phaseolus vulgaris L.), raw shelled peanuts (Arachis hypogaea L.), and mature seeds of soybean, which were replaced every week. The rearing cages were kept in a walk-in chamber at $25 \pm 1{ }^{\circ} \mathrm{C}$ temperature, $65 \pm 10 \% \mathrm{RH}$ and L14:D10 photoperiod. Egg masses laid on commercial cotton balls provided as egg substrates were collected twice per week and placed inside small plastic boxes $(11 \times 11 \times 3.5 \mathrm{~cm})$. Nymphs were raised to adults using the foods mentioned above in the walk-in chamber.

Seeds of maize hybrid P1630 H (Pionner ${ }^{\circledR}$ ) were seeded weekly in small plastic pots $(100 \mathrm{~mL})$ and kept in a greenhouse. Maize plants in the stage V2 (two leaves completely developed according to Ritchie and Hanway (1989) scale) were used in the experiments. Plants were utilized in this stage of development because bugs feed on their stems at this time.

\subsection{Evaluation of the body position and data acquisition}

To determine the body position of $D$. melacanthus on maize stems, adult bugs $(\mathrm{n}=10)$ of similar age (ca. two weeks) were kept individually inside small plastic cages (tubes with length $=6.0 \mathrm{~cm}$, diameter $=2.5 \mathrm{~cm}$ ) positioned surrounding each plant stem. One end of each tube was inserted into the soil and the other was closed with a cotton wad to prevent scape. Tubes were kept in the walk-in chamber with environmental conditions as previously described. Data were taken daily during 30 days; for each day, ten observations were taken every hour, totalizing 300 observations per bug evaluated. Plants were changed weekly.

During the observations, we recorded the number of bugs that were on the plant, the number of bugs that were on the soil or on the tube, and the number of bugs on the stem feeding, and not feeding, in the upward or downward position (Table 1). To compare body position, we considered only the bugs positioned on stem of each plant (head pointed downward or upward), and whether the bug was feeding (mouthparts [stylets] inserted into plant tissue) or not feeding.

Table 1. Observations recorded for adult Dichelops melacanthus placed individually inside plastic cages (tubes) positioned surrounding each maize plant stem during 30 days, observed 10 times daily, 10 individuals, totalizing 3,000 observations.

\begin{tabular}{lcc}
\hline \multicolumn{1}{c}{$\begin{array}{c}\text { Parameters } \\
\text { observed }\end{array}$} & $\begin{array}{c}\text { Number } \\
\text { recorded }\end{array}$ & $\begin{array}{c}\text { Percentage } \\
\text { calculated }\end{array}$ \\
\hline Bugs out of the plant & 1,829 & 61.0 \\
Bugs on the plant & 1,171 & 39.0 \\
Bugs in downward & 514 & 17.1 \\
position & & \\
Feeding & 293 & 9.8 \\
Not feeding & 221 & 7.4 \\
Bugs in upward & 657 & 21.9 \\
position & & \\
Feeding & 64 & 2.1 \\
Not feeding & 593 & 19.8 \\
\hline
\end{tabular}




\subsection{EPG waveforms recording}

The feeding behavior of $D$. melacanthus was investigated using the EPG technique. In EPG, a low electrical current pass through the system formed by insects and plants. The EPG record waveforms that represent different feeding activities (e.g., Walker, 2000). The waveforms related to feeding behavior of $D$. melacanthus were recorded based on waveform library recently published for this species (Lucini and Panizzi, 2017). For this study, we considered only waveforms related to ingestion.

Because bugs feed on seedlings, maize plants in the stage V2 (two leaves completely developed) were used to record the feeding behavior of D. melacanthus. Adult females (females are usually used for EPG recordings) $(n=10)$ were previously separated from colony and starved for 15 hours before wiring (bugs were starved to stimulate feeding); after that, each individual insect was attached on the gold wire (to make part of the electrical circuit) according to the methodology used by Lucini and Panizzi (2016). This methodology consists in sanding the cuticle of the pronotum of bugs to improve the wire attachment.

The feeding behavior of bugs was recorded continuously for 8 hours in a closed room kept at $25 \pm 2{ }^{\circ} \mathrm{C}$ with artificial light. Four bugs were recorded simultaneously, and when they were feeding the waveforms generated and body position were correlated. A four-channel EPG AC-DC monitor (Backus and Bennett, 2009; EPG Technologies, Inc., Gainesville, FL, USA) was used, and at all channels were applied an input impedance (Ri) of $10^{7} \mathrm{Ohms}$ and $50 \mathrm{mV}$ alternating current $(\mathrm{AC})$. Insects, plants and amplifiers (channels) were kept inside a Faraday cage. The output signals generated during feeding recording were captured, amplified, and digitized at a rate of 100 samples per $\mathrm{s}$ per channel using a DI-710 (Dataq Instruments, Akron, $\mathrm{OH})$ linked at a HP Pentium notebook with WinDaq Lite software (Dataq).

\subsection{Plant histology}

Maize plants in the stage V5 (five leaves completely developed of Ritchie and Hanway (1989) scale) were used to make the cross-section of the plant tissue to correlate the stylet and/or salivary sheath tip with a specific waveform. This was done because in the earlier stages of plant development (V2) the stems were too soft to allow the proper cuttings for histology.

During recordings, the EPG monitor was turn off when the waveforms related to ingestion was recorded $(n=10)$, based on waveform library create for $D$. melacanthus on maize seedlings (Lucini and Panizzi, 2017). After that, maize stems were processed according to the methodology applied by Lucini and Panizzi (2016) to prepare semi-permanent slides. These slides were used to obtain digital images, using an Olympus BX50 (Shinjuku, Tokyo, Japan) microscope coupled with a Sony DXC 107A video camera (Minato, Tokyo, Japan) linked to a desk computer.

\subsection{Statistical analysis}

Data obtained on observations of the body position of $D$. melacanthus on stems of maize seedlings, feeding and not feeding in each body position, were calculated.
Because data referred to the same individual observed several times along the observation period, the Pearson's chi-squared test $\left(\chi^{2}\right)$ was considered the statistical test suitable to test the set of categorical data referred above. This will allow to evaluate how likely it is that any observed difference between the sets arose by chance. All analyses were carried using R program, v.3.0.3 (R Development Core Team, 2014).

\section{Results}

From the total 3,000 observations carried out on the different parameters observed pointed in Table 1, the majority (over $60 \%$ ) of the bugs were found out of the plants, either on the soil or on the tube cage. On the plants, the percentages of bugs either on the downward position, i.e., with heads pointed down, or on the upward position, i.e., with heads pointed up, was similar (ca. $17 \%$ to $22 \%$ ). When downward, the percentage of bugs feeding (stylets inserted into plant tissue) or not feeding was also similar; when upward, the majority of bugs were not feeding. However, when comparing the feeding activity only, a much greater number of bugs (over four times) were recorded in the downward that in the upward position (Table 1).

Data calculated on feeding downward vs. upward indicated a significantly greater number of times bugs feeding downward compared to feeding in the upward position $\left(\chi^{2}=147.7, \mathrm{df}=1, \mathrm{P}<0.001\right)$. In contrast, when the bugs were not feeding the opposite was observed, with significantly greater number of times bugs in the upward compared to those in the downward position $\left(\chi^{2}=170.0\right.$, $\mathrm{df}=1, \mathrm{P}<0.001)$ (Figure 1).

During EPG essays with D. melacanthus on maize stem we observed a similar behavior, with the majority of the bugs evaluated keeping their heads downward while the stylets were inserted into the plant tissue (Figure 2A). At this time, the EPG monitor registered two types of feeding waveforms. The type 1 (Figure 2B), presented a

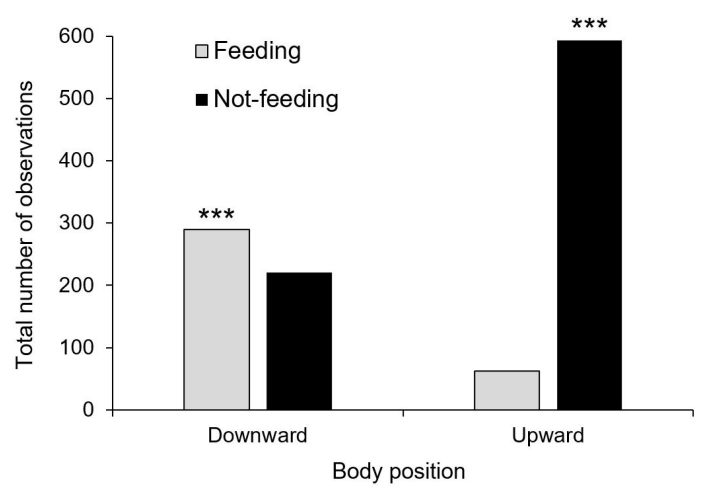

Figure 1. Body position of Dichelops melacanthus on maize plant stems during feeding and not feeding. Asterisks $(* * *)$ indicates significant differences between the two body positions during each activity according to Chi-Square test $\left(\chi^{2}\right)$ at $\mathrm{P}<0.001$. 
stereotypical pattern composed by repetitive wave portions interspersed with downward peaks occurring at regular intervals over the entire waveform (Figure 2C). The type 2 (Figure 2D) showed two different patterns: the first one always showed peaks randomly distributed, with certain regularity and often downward oriented (Figure 2E); and the second pattern showed a high regular frequency and short duration, always interspersed with the first pattern (Figure 2E). Both types of waveforms were observed in all insects recorded $(n=10)$.
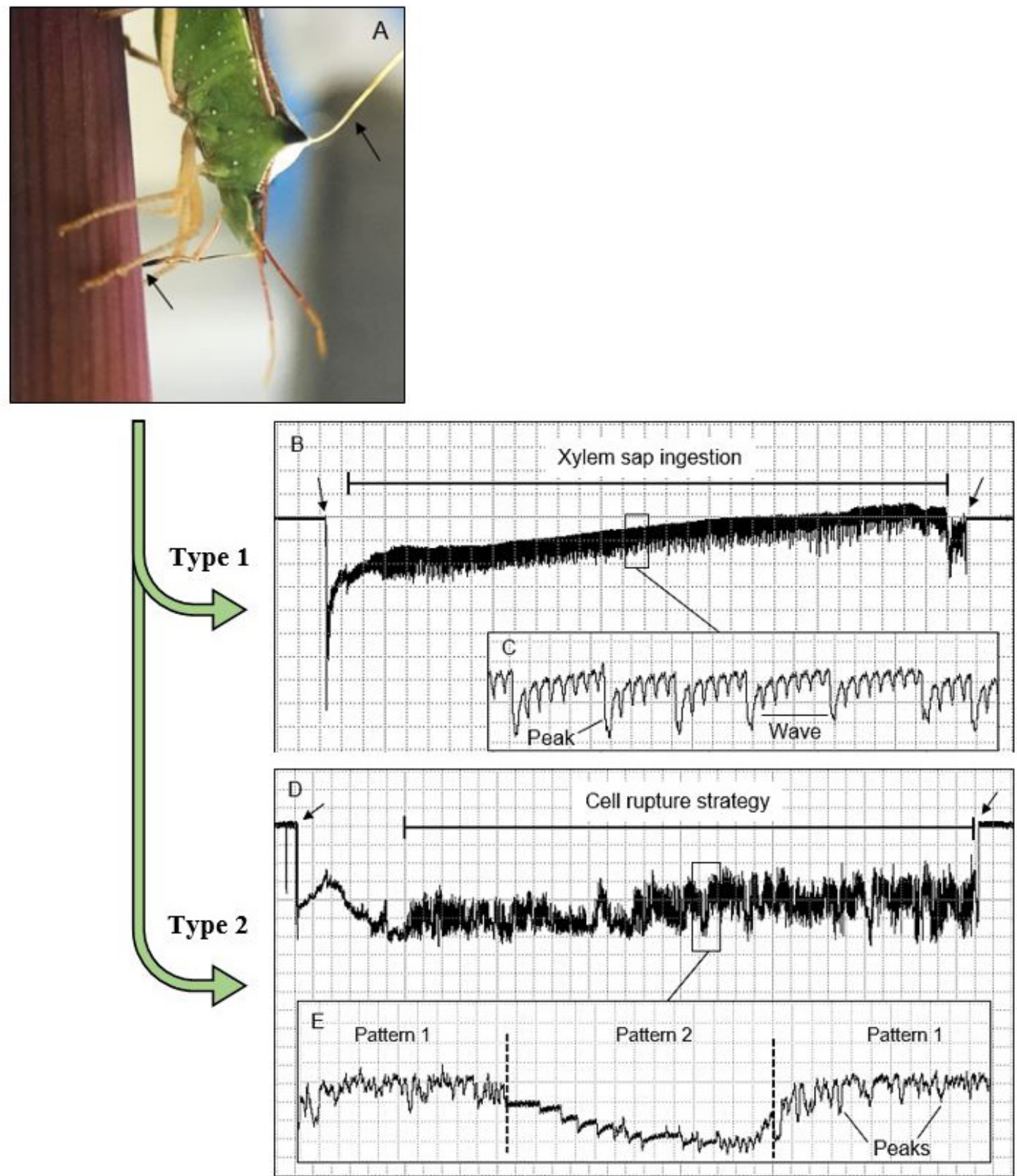

Figure 2. Dichelops melacanthus connected to the gold wire (arrow) during EPG recordings on maize plant stem and positioned in the downward position with their stylets inserted into plant stem (arrow) during feeding activities (A). Feeding behavior of $D$. melacanthus on stems of maize seedlings showing a compressed overview of a single waveform correlated with xylem sap ingestion (B). Detail of xylem waveform showing the repetitive pattern composed by wave portion interspersed with downward peaks (C). Overview of the waveform correlated with cell rupture strategy on stems of maize seedlings (D). Details of the two different patterns of the cell rupture waveform (E). (B has Windaq compression 250 [50 s/vertical div.], gain 16x; C has compression 3 [0.6 s/vertical div.], gain 32x, D has compression 100 [20 s/vertical div.], gain 16x; E has compression 5 [1 s/vertical div.], gain 16x). Arrow heads in Figures B and D indicate beginning or end of a probe. 
The histological images generated when the stylets were cut during these feeding waveforms, demonstrated that during the first type the severed stylets and/or the salivary sheath tips ended in the xylem vessels (Figure 3A). In the second waveform type, the stylet tips were always positioned in the parenchyma tissue without a specific position or feeding site inside the plant tissue (Figure 3B).

\section{Discussion}

We present and discuss data on the body position of D. melacanthus feeding and not feeding on stem of maize seedlings. The preferred downward position during feeding, although referred to several species of pentatomids, such as E. meditabunda on soybean stem (Panizzi and Machado-Neto, 1992), T. limbativentris on rice stem (Ferreira and Martins, 1984) and D. melacanthus on maize stem (Ávila and Panizzi, 1995) was never quantified and demonstrated. More recently, two other species of pentatomids were reported to feed on rice stem downward (again, not quantified): Hypatropis inermis (Stål) (Krinski et al., 2015) and the small black stem bug, Glyphepomis spinosa Campos \& Grazia, which is considered a new pest on rice in the central and northern Brazilian states (Alves et al., 2012).

The fact that the majority of the bugs were recorded out of the plants during the observations suggests that maize, although highly susceptible to $D$. melacanthus feeding activity with resulting severe damage to seedlings (Ávila and Panizzi, 1995), is not a preferred host plant. In a review of literature, Smaniotto and Panizzi (2015) refer to several references of $D$. melacanthus reproducing mostly on Fabaceae; on Poaceae, of the 10 species referred to be associated with the bug, only wheat, Triticum aestivum L. is reported to allow complete nymph development but not to allow adult reproduction. Therefore, maize plants at the seedling stage of development may provide mostly water to the bugs, and this may help to keep the nutrient concentration in a suitable balance.

Herein we demonstrated via EPG studies that D. melacanthus on stems of maize plants produced two feeding waveforms types. The first type, represented the ingestion of sap from xylem vessels and the second one represented the cell rupture strategy, where the stink bug use de lacerate and macerate activities to break a pocket of cells and then ingest the contents. These waveforms were similar in appearance and electrical characteristics to those published to $D$. melacanthus on maize seedlings [see Lucini and Panizzi (2017) for more details].

It can be speculated that species of pentatomids that feed (ingest liquid food and/or water) from xylem cells of vegetative structures (for example, stems) position their body downward to facilitate the process. This position might facilitate the intake of the xylem sieve that moves upward, i.e., from roots to leaves (Taiz and Zeiger, 2004) (see diagrammatic and hypothetical illustration Figure 4A). In contrast, in the upward position, the flow of the xylem sap runs away, making the ingestion process harder (Figure 4B). However, the xylem vessels are controlled by a strong negative tension, which sucking insects need to overcome to uptake the liquid (Dugravot et al., 2008); this may invalidate this hypothesis, because the negative tension prevent the sap to move freely into the openings of the stylet tips. Moreover, bugs do not feed exclusively from xylem tissues as demonstrated with the EPG/histology study.

Several other cues might influence the bug's body position on stem of host plants, which include sunlight, gravity, orientation of hairs on the plant, avoidance of natural enemies attack, etc. However, the fact that during not feeding activities on maize stem, the majority of bugs
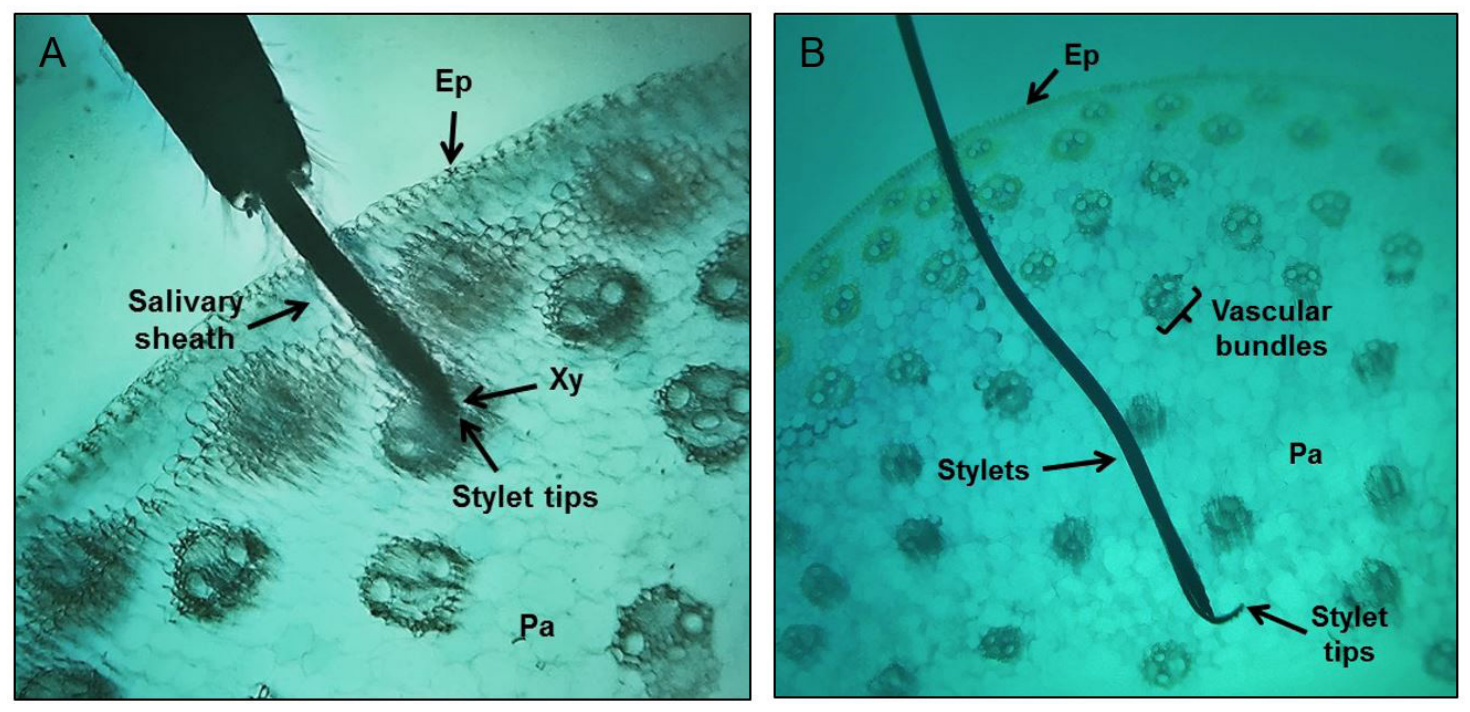

Figure 3. Cross-sections of maize stems showing Dichelops melacanthus stylets in xylem vessels (A). Stylets positioned in the parenchyma tissue during the cell rupture strategy (B). Ep: epidermis; Pa: parenchyma; Xy: xylem vessel. 

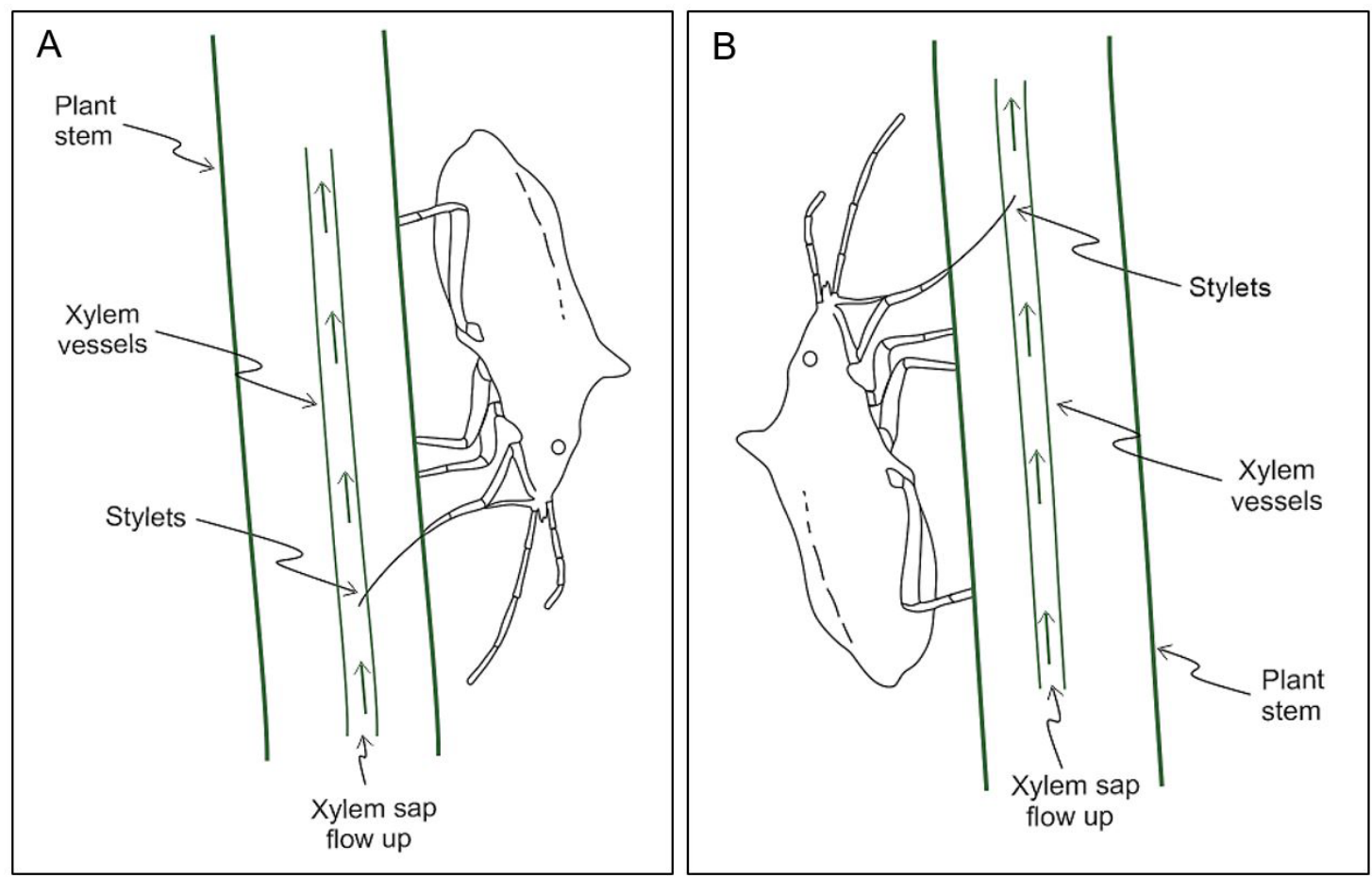

Figure 4. Schematic and hypothetical representation of stink bug body position while feeding from xylem vessels on stems of maize plants. Downward display with stylets positioned against the xylem sap flow direction (A), which presumably facilitates the liquid food ingestion; upward display with stylets positioned following the xylem sap flow direction (B), which presumably make harder the liquid food intake.

remain upward, and during feeding they remain downward, makes one to believe that the downward position facilitates the intake of cell contents. Clearly, additional studies are needed to explain this "body position syndrome" fully. This information coupled with the feeding sites might add new insights to improve the efficacy of the chemical control of phytophagous stink bugs by systemic insecticides.

\section{Acknowledgements}

We thank Júlio César Minosso for help in the laboratory and greenhouse activities. This study was partially supported by a Conselho Nacional de Desenvolvimento Científico e Tecnológico (CNPq) grant 471517/2012-7 to ARP, and by a scholarship from CAPES (Ministry of Education) of Brazil to TL. We also thank the Embrapa Unit at Passo Fundo, RS, for support. Approved by the Publication Committee of the Embrapa Trigo, Passo Fundo, RS, Brazil, under number 5419/2017.

\section{References}

ALVES, T.M., BARRIGOSSI, J.A.F. and QUINTELA, E.D., 2012. Life cycle of Glyphepomis spinosa Campos \& Grazia (Hemiptera: Pentatomidae): a new pest of rice in Brazil. Neotropical Entomology, vol. 41, no. 6, pp. 437-441. http://dx.doi.org/10.1007/ s13744-012-0067-3. PMid:23949667.
ÁVILA, C.J. and PANIZZI, A.R., 1995. Occurrence and damage by Dichelops (Neodichelops) melacanthus (Dallas) (Heteroptera: Pentatomidae) on maize. Anais da Sociedade Entomológica do Brasil, vol. 24, pp. 193-194.

BACKUS, E.A. and BENNETT, W.D., 2009. The AC-DC correlation monitor: new EPG design with flexible input resistors to detect both $\mathrm{R}$ and emf components for any piercing-sucking hemipteran. Journal of Insect Physiology, vol. 55, no. 10, pp. 869-884. http://dx.doi.org/10.1016/j.jinsphys.2009.05.007. PMid:19482032.

CHOCOROSQUI, V.R. and PANIZZI, A.R., 2004. Impact of cultivation systems on Dichelops melacanthus (Dallas) (Heteroptera: Pentatomidae) populations and damage and its chemical control on wheat. Neotropical Entomology, vol. 33, no. 4, pp. 487-492. http://dx.doi.org/10.1590/S1519-566X2004000400014.

DUGRAVOT, S., BACKUS, E.A., REARDON, B.J. and MILLER, T.A., 2008. Correlations of cibarial muscle activities of Homalodisca spp. Sharpshooters (Hemiptera: Cicadellidae) with EPG ingestion waveform and excretion. Journal of Insect Physiology, vol. 54, no. 12, pp. 1467-1478. http://dx.doi. org/10.1016/j.jinsphys.2008.05.008. PMid:18789944.

FERREIRA, E. and MARTINS, J.F.S., 1984. Insetos prejudiciais ao arroz no Brasil e seu controle. Goiânia: Embrapa-CNPAF, 67 p. Doc, no. 11.

GALILEO, M.H.M. and HEINRICHS, E.A., 1979. Danos causados à soja em diferentes níveis e épocas de infestação durante o crescimento. Pesquisa Agropecuária Brasileira, vol. 14 , no. 3, pp. 279-282. 
KRINSKI, D., FOERSTER, L.A. and GRAZIA, J., 2015. Hypatropis inermis (Hemiptera, Pentatomidae): first record on rice crops. Revista Brasileira de Entomologia, vol. 59, no. 1, pp. 12-13. http://dx.doi.org/10.1016/j.rbe.2014.11.001.

LUCINI, T. and PANIZZI, A.R., 2016. Waveform characterization of the soybean stem feeder Edessa meditabunda : overcoming the challenge of wiring pentatomids for EPG. Entomologia Experimentalis et Applicata, vol. 158, no. 2, pp. 118-132. http:// dx.doi.org/10.1111/eea.12389.

LUCINI, T. and PANIZZI, A.R., 2017. Feeding behavior of the stink bug Dichelops melacanthus Dallas on maize seedlings: an EPG analysis at multiple input impedances and histology correlation. Annals of the Entomological Society of America, vol. 110, no. 2, pp. 160-171. https://doi.org/10.1093/aesa/saw070.

MANFREDI-COIMBRA, S., SILVA, J.J., CHOCOROSQUI, V.R. and PANIZZI, A.R., 2005. Danos do percevejo barriga-verde Dichelops melacanthus (Dallas) (Heteroptera: Pentatomidae) em trigo. Ciência Rural, vol. 35, no. 6, pp. 1243-1247. http://dx.doi. org/10.1590/S0103-84782005000600003.

PANIZZI, A.R. and MACHADO NETO, E., 1992. Development of nymphs, and feeding habits of nymphal and adult Edessa meditabunda (Heteroptera: Pentatomidae) on soybean and on sunflower. Annals of the Entomological Society of America, vol. 85, no. 4, pp. 477-482. http://dx.doi.org/10.1093/aesa/85.4.477.

PANIZZI, A.R., AGOSTINETTO, A., LUCINI, T., SMANIOTTO, L.F. and PEREIRA, P.R.V.S., 2015. Manejo integrado dos percevejos barriga-verde, Dichelops spp. em trigo. Passo Fundo: Embrapa Trigo, 40 p. Doc, no. 114.
R DEVELOPMENT CORE TEAM, 2014. $R$ : A language and environment for statistical computing [software]. Vienna: $\mathrm{R}$ Foundation for Statistical Computing.

RITCHIE, S. and HANWAY, J.J., 1989. How a maize plant develops. Ames: Iowa State University of Science and Technology, Cooperative Extension Service. Special Report, no. 48.

RIZZO, H.F.E., 1976. Hemípteros de interés agrícola. Buenos Aires: Hemisferio Sur.

SCHUH, R.T. and SLATER, J.A., 1995. True bugs of the world (Hemiptera: Heteroptera): classification and natural history. Ithaca: Cornell University Press.

SILVA, F.A.C., SILVA, J.J., DEPIERI, R.A. and PANIZZI, A.R., 2012. Feeding activity, salivary amylase activity and superficial damage to soybean seed by adult Edessa meditabunda (F.) and Euschistus heros (F.) (Hemiptera: Pentatomidae). Neotropical Entomology, vol. 41, no. 5, pp. 386-390. http://dx.doi.org/10.1007/ s13744-012-0061-9. PMid:23950088.

SMANIOTTO, L.F. and PANIZZI, A.R., 2015. Interaction of selected species of stink bugs (Hemiptera: Heteroptera: Pentatomidae) from leguminous crops with plants in the neotropics. The Florida Entomologist, vol. 98, no. 1, pp. 7-17. http://dx.doi. org/10.1653/024.098.0103.

TAIZ, L. and ZEIGER, E., 2004. Plant physiology. 3rd ed. Sunderland: Sinauer Associates Inc. Publishers, 690 p.

WALKER, G.P., 2000. A beginner's guide to electronic monitoring of homopteran probing behavior. In: G.P. WALKER and E.A. BACKUS, eds. Principles and applications of electronic monitoring and other techniques in the study of homopteran feeding behavior. Annapolis: Entomological Society of America, pp. 14-40. 